tejido vegetativo de escamas de bulbo. Las respuestas fluctuaron entre 0 y $15 \%$ de brotación en $R$. rhodolirion hasta $0-50 \%$ en $R$. splendens al usar escamas simples o gemelas. La germinación de semillas in vitro permitió incorporar gran cantidad de genotipos a cultivo dando origen a un banco de germoplasma de más de 1100 accesiones de las 4 especies en estudio. Posteriormente, se agregó $R$. laeta, a partir de bulbos, con una buena respuesta al cultivo in vitro. Del mismo modo, la utilización de medios líquidos estacionarios, permitieron buenos progresos en mejorar la eficiencia de cultivo in vitro en las cinco especies en estudio.

Los trabajos de engorda de bulbillos, realizados en Talca, permitieron resultados promisorios en términos de aumento de calibre, por efecto de diversos tratamientos de control ambiental. Del mismo modo, se ha observado floración bajo condiciones de invernadero con calibres variables según la especie, por ej.: $R$. rhodolirion, calibres $7 / 9$ a $14 / 16, R$. splendens, $3 / 4$ a $5 / 6, R$. montana, $1 / 2$ a $5 / 6$ y $R$. bagnoldii, calibres $7 / 9$ a $20 / 21$, con floraciones que se producen entre junio y enero.

Trabajo Financiado por Proyecto FIA- BIOT-01-A-071

Agro Sur 34 (1-2):7-9 2006

\title{
AVANCES EN LA MICROPROPAGACIÓN DE PLANTAS ORNAMENTALES
}

\section{ADVANCES IN THE MICROPROPAGATION OF ORNAMENTAL PLANTS}

\section{Daquinta, M.}

Laboratorio de Cultivo de Células y Tejidos. Centro de Bioplantas. Universidad de Ciego de Ávila. Carretera a Morón Km. 9. CP 69450. Cuba, e-mail: mdaquinta@bioplantas.cu

La micropropagación de plantas ornamentales encontró una gran aplicación en el campo de la horticultura. La comercialización de plantas decorativas de follajes y flores es de cientos de millones de unidades, de los cuales alrededor del $80 \%$ se produce con el empleo de esta tecnología. Se prevé un crecimiento anual del consumo en el mercado mundial de productos florícolas, por lo que es necesario mejorar las metodologías de propagación in vitro para satisfacer estas crecientes demandas. La inmersión temporal es una técnica que ha permitido el incremento de los coeficientes de multiplicación con la disminución de los costos de producción. El uso del medio líquido para la propagación in vitro tiene algunas ventajas y se considera una técnica ideal para la propagación masiva de plantas, porque reduce la manipulación y es un requisito indispensable para la automatización del proceso (Aitken-Christie, 1991). Sin embargo, su principal desventaja es que provoca la hiperhidricidad de los tejidos de los brotes. Para evitar este desorden fisiológico, se han desarrollado diferentes procedimientos, entre los que se encuentran el cultivo en agitación, el empleo de soportes alternativos como puentes de papel de filtro, tapones de celulosa, la técnica de doble capa, el enfriamiento del fondo del frasco de cultivo, etc., así como el empleo de agentes químicos antivitrificantes.

Alvard et al. (1993) estudiaron cinco métodos diferentes de cultivo en comparación con el cultivo en medio sólido en la propagación de meristemos de bananos. A partir de estos resultados surgió un nuevo concepto para el cultivo in vitro en medio líquido: la inmersión temporal (Teisson y Alvard, 1995). Esta técnica se ha empleado exitosamente con Coffea, Hevea, Musa, Citrus ya sea mediante proliferación de meristemos, cultivo de microestacas, desarrollo de embriones a partir de callos, germinación y conversión de embriones somáticos. La calidad del desarrollo de los brotes es generalmente mejor a la que se obtiene con el empleo del medio líquido o semi-sólido. La micropropagación de plantas requiere la transferencia periódica del cultivo a medio fresco debido al agotamiento y/o alteración de los nutrientes, así como, al 
crecimiento o proliferación del tejido, que sobrepasa la capacidad del frasco de cultivo. Generalmente los cultivos se mantienen en frascos individuales y se transfieren a medio fresco en un intervalo de cuatro a seis semanas. Algunos sistemas de micropropagación alternativos con el empleo de medio líquido se han desarrollado con el propósito de la automatización del proceso y la consiguiente reducción de los costos. Teisson y Alvard (1995) desarrollaron un aparato para la micropropagación de plantas a partir de la modificación de una unidad de filtración Nalgene de $250 \mathrm{~mL}$ de capacidad cuyo nombre comercial es RITA. En Israel, un grupo de investigadores han diseñado un biorreactor desechable para el cultivo de órganos que actualmente comercializa la firma OSMOTEK.

En Cuba, a partir del desarrollo del primer sistema semi-automatizado de inmersión temporal en 1997, se han realizado investigaciones sobre la aplicación de esta técnica en la proliferación de meristemos de caña de azúcar (Lorenzo et al., 1998), para el cultivo intensivo de microtubérculos de papas (Jiménez et al.. 1998), para la propagación in vitro de la pina (Escalona et al., 1999) y para la proliferación de bananos (Daquinta et al., 1999).

El sistema consiste de dos recipientes, mangue- ras, filtros hidrofóbicos de $0,2 \mu \mathrm{m}$, electroválvulas y un compresor de aire. Un frasco es el vaso de cultivo para los explantes y el otro, el recipiente para el medio de cultivo. Ambos fras$\cos$ se comunican a través de mangueras. Las baterías de cultivo se colocan en estantes con condiciones ambientales controladas. La frecuencia y el tiempo de inmersión se controlan a través de un autómata, el cual hace que se abre una válvula y el aire impulsa el medio de cultivo hacia el frasco que contiene los explantes. Durante el período de inmersión, el aire permite el burbujeo del medio, remueve los explantes y cambia la atmósfera dentro del recipiente del cultivo. Pasado el tiempo de inmersión, se activa una segunda válvula y regresa el medio al recipiente de almacenamiento.

El SIT tiene dos posibilidades de aplicación: para la obtención de explantes y su ulterior proliferación en frascos convencionales de la micropropagación o para la obtención de brotes aptos para el enraizamiento ex vitro y la aclimatización.

En el cuadro 1 se resumen los coeficientes de multiplicación que se han alcanzado en los diferentes cultivos ornamentales con el empleo del SIT.

Cuadro 1. Coeficientes de multiplicación en la micropropagación convencional y mediante el uso de SIT. Table 1. Multiplication coefficients in conventional propagation and using TIS.

\begin{tabular}{lccc}
\hline \multicolumn{1}{c}{ Cultivo } & Variedad & Micr. Convencional & Inmersión Temporal \\
\hline Syngonium & W. Butterfly & 7.3 & 28.0 \\
& Pixie & 2.2 & 18.4 \\
Spathyphyllum & Sensation & 3.7 & 17.6 \\
Phylodendrom & Xanadu & 2.0 & 8.8 \\
\hline
\end{tabular}

En todos los casos el tiempo y la frecuencia de inmersión fueron de 2 minutos cada tres horas. No se detallan las condiciones de cultivo en particular para cada especie.

\section{BIBLIOGRAFIA.}

AITKEN-CHRISTIE, J. 1991. Automation. In: Debergh, P.C.; Zimmerman, R.H. (eds.). Micropropagation .Netherland, Kluwer Academic Publishers, pp 358-363

AITKEN-CHRISTIE, J.; DAVIES, H. 1988. Development of a semi-automated micropropagation system. Acta Horticulturae 230: 81-87
ALVARD, D.; COTE, F.; TEISSON, C. 1993. Comparison of methods of liquid medium culture for banana micropropagation. Effect of temporary immersion of explants. Plant Cell, Tissue and Organ Culture 32: 55-60

DAQUINTA, M.; BARRERA, L.; LEZCANO, Y, MOSQUEDA, O.; ESCALONA, M.; BORROTO, C.G. 1999. Efecto de la oscuridad en la multiplicación in vitro del banano FHIA-18 en los sistemas 
de inmersión temporal. Libro de Reportes Cortos. 5to Coloquio Internacional de Biotecnología Vegetal: pp 185-187.

ESCALONA. M.; LORENZO, J.C.; GONZALEZ, B.; DAQUINTA, M.; GONZALEZ, Y; ESJARDINS, J.L.; BORROTO, C.G. 1999. Pineapple (Ananas comosus L. Merr.) micropropagation in temporary immersion systems. Plant Cell Reports $18: 743-748$. antivitrifying agents. Canadian Journal Plant Science 73: 231-235.

JIMENEZ, E.; PEREZ, N.; M DE FERIA, R.; BALBOA, R.; CAPOTE, A.; CHAVEZ, M.; QUIALA, E.; PEREZ, J.C. 1998. Improved production of potatoes (Solanum tuberosum L.) microtubers using temporary immersion systems. Plant Cell, Tissue and Organ Culture 54 :

LORENZO, J C.; GONZALEZ, B.; ESCALONA, M.; TEISSON. C.; ESPINOSA, P.; BORROTO, C.G. 1998. Sugar cane shoot formation in an improved Temporary Immersion System. Plant Cell, Tissue and Organ Culture. 54 : 197-200.

TEISSON C.; ALVARD, D. 1995. A new concept of plant in vitro cultivation liquid medium: Temporary Immersion. In: Terzi, M.; Cella, R.; Falavigna, A. (eds.). Current Issues in Plant Molecular and Cellular Biology. Netherland, Kluwer Academic Publishers, pp. 105-109

\title{
LOGISTICA EN LA COMERCIALIZACIÓN Y EXPORTACIÓN DE FLORES
}

\section{LOGISTICS IN SALE AND EXPORT OF FLOWERS}

\author{
Puiggros, A., Gerente General AC Mater. Av. Lo Narváez s/n, Olmué - V Región. \\ E-mail:apv@acmater.cl
}

La logística en la comercialización de flores cortadas debe ser analizada en un contexto que abarque todos los procesos involucrados en el negocio propiamente tal, desde la planificación inicial de la compra del material vegetal inicial hasta la obtención de la re-compra.

En la actualidad los manejos logísticos para el mercado nacional y para el mercado de exportación de flores difieren enormemente, ¿Es esto lógico? ¿Por qué una flor que se comercialice en Chile debe ser manejada en forma distinta a la que se vende en otros países?

Para poder analizar los diferentes aspectos logísticos dentro del negocio de producción y comercialización de flores hay que identificar los aspectos claves y clasificarlos según si son productivos, de poscosecha o comerciales.

¿Qué hacer para poder mantenerse en el tiempo en el negocio de producción y comercialización de flores de corte? Hay que lograr lo que he definido las tres "C" del negocio: Compromiso,
Consistencia y Cumplimiento.

Los principales puntos a abordar son los siguientes:

* La comercialización de flores en el contexto general del negocio. No solo hay que vender, la sustentabilidad del negocio va más allá que eso.

* Nociones del concepto de logística. Hay que tener los límites bien claros.

* Aplicación del concepto DMAMC: Todo factor relevante debe ser Definido, Medido, Analizado, Mejorado y Controlado.

* La logística en un proceso de exportación de flores frescas. Análisis de los puntos críticos en el proceso de exportación.

* La logística en un proceso de comercialización de flores a nivel local. Análisis de la realidad local.

* Diferencias entre el proceso exportador y la venta local.

* ¿Cómo mantenerse en el tiempo? 